\title{
NON-RANDOM DISTRIBUTION OF BIOCRUST IN A NATURAL ARID ENVIRONMENT IN THE NORTHERN MEXICAN PLATEAU
}

\author{
GutiÉRrEZ, M. ${ }^{1}$ - PANDO-MORENO, M. ${ }^{1 *}$ - JURADO, E. ${ }^{1}$ - GONZÁLEZ-RODRÍGUEZ, H. $^{1}$ - \\ MARMOLEJO, J. G. ${ }^{1}-$ MENDOZA, D. ${ }^{2}$ \\ ${ }^{1}$ Facultad de Ciencias Forestales, Universidad Autónoma de Nuevo León \\ Carr. Nac. Km 145, Linares, Nuevo León, Mexico \\ (phone: +52-821-212-4895) \\ ${ }^{2}$ Universidad Rey Juan Carlos, Calle Tulipán, s/n, 28933 Móstoles, Madrid, Spain \\ (phone: +34-91-665-5060) \\ *Corresponding author \\ e-mail:mpando55@hotmail.com \\ (Received $16^{\text {th }}$ Jan 2018; accepted $3^{\text {rd }}$ Apr 2018)
}

\begin{abstract}
Biocrust, as photosynthetic organisms, has been considered to show an inversely proportional relationship with vascular plant cover. However, some studies report association and facilitation relationships between them. This research explores whether i) biocrust is associated with shrub species, ii) biocrust cover is higher in undershrub microenvironments than in open areas between plants and, iii) soil moisture and solar radiation affect biocrust distribution. Biocrust cover was analyzed by morphotype in microenvironments under the canopy of two dominant shrub species (Larrea tridentata and Parthenium incanum) and in open areas. Soil moisture and solar radiation were recorded at each microenvironment. Thirty-three interception lines (975 points) were used to analyze the association between vascular plants and biocrust and 20 sampling plots to estimate morphotype cover. Results reveal a positive association between biocrust and plant species compared to open areas. Lichens and cyanobacteria showed a higher cover under $L$. tridentata than under $P$. incanum and in open areas, suggesting a species-specific facilitative association with $L$. tridentata, maybe due to a higher soil water content in this microenvironment. Mosses had lower cover in the open area where the highest solar radiation was recorded. Lichens and cyanobacteria distribution appeared to be related to soil moisture.

Keywords: creosote bush, cyanobacteria, lichens, mosses, northeastern Mexico
\end{abstract}

\section{Introduction}

Biological soil crusts are made up of extremely long-lived organisms, they provide continuous ecosystem services (Castillo-Monroy and Maestre, 2011) and have been considered as long term environmental indicators (Belnap et al., 2001) that provide structure to the soil (Richer et al., 2012), contribute to water balance, erosion control and nutrient cycling (Castillo-Monroy and Maestre, 2011). Furthermore, the presence of lichen crusts improves soil resistance to erosion and increases its water holding capacity (Abed et al., 2013).

Vegetation dynamics and the microenvironments that plants create affect biological crust distribution (Zhao et al., 2010) particularly in arid environments where plant species are arranged in patches on a bare soil matrix (Puigdefábregas and Sánchez, 1996) creating islands of resources (Reynolds, 1999). However, the way vascular plant cover affects the biological soil crust (BSC) distribution remains controversial; some authors have found a positive relation between shrub cover and total BSC cover, but a negative relation with lichen cover (Ochoa-Hueso et al., 2011; Root and McCune, 2012). Others report that BSC cover and species richness was higher in microsites 
without vegetation, either grazed or cultivated than in vegetated sites (Eldridge et al., 2000). The relationship between cover of biological crusts and vascular plants has been found to be inversely proportional (Belnap et al., 2001).

Vascular plants are successful competitors for resources such as light, nutrients, and water (Löbel et al., 2006) and this may result in a disadvantage for BSC growing under them. However, microenvironments under shrubs are likely to have more nutrients and higher water holding capacity, thus favoring the BSC development (Bowker et al., 2005); creating facilitation relationships between vascular plants and BSC as has been shown for Stipa tenacissima and Cladonia convoluta in Spain (Maestre, 2003).

Biological soil crusts dominated by mosses are usually more abundant in moist microenvironments of arid and semiarid environments (Maestre et al., 2001). In these environments, the presence of vascular vegetation may favor the occurrence of some components of BSC (mainly bryophytes), since it may provide moister microsites protected from direct solar radiation (Concostrina-Zubiri et al., 2014; Núñez and Toledo, 2013; Haughian and Burton, 2015). Contrarily, crusts constituted mainly by lichens are related to the areas most exposed to solar radiation and heat, with low moisture and nutrient availability (Haughian and Burton op cit.), even though the water availability has been considered critical for the establishment and development of lichens (Gignac, 2001). Open areas with the dominance of BSC have been found to have the higher cover of cyanobacteria and lichens and less of mosses compared with microsites under the canopy of plants (Mendoza-Aguilar et al., 2014).

However, Gutiérrez et al. (2017) found a higher cover of lichens, cyanobacteria, and mosses underneath vascular plants than in open areas and considered that this might be due to a lower competition for space between the BSC components than in other areas that have higher densities of these components. Because BSC components do not have roots to uptake water and nutrients, these resources are likely to be captured from the atmosphere or through direct contact with the soil (St. Clair et al., 2002). Thus, competition for space becomes very important for BSC components, because it secures access to more resources (Bowker et al., 2010).

These contrasting results highlight the relevance of continuous evaluation of the BSC component distribution and their relation to vascular plant species, exploring association, facilitation and competition relationships between them. This, in turn, may have an impact on nutrient and water flux dynamics and in the overall functioning of the ecosystem. Hence, this research is aimed at determining whether there is a positive or negative association between BSC and vascular plants or they are randomly distributed and whether this distribution pattern is equal for all the components of the BSC in the area.

The Mexican Plateau floristic Province (Rzedowski, 2006) is dominated by arid and very arid climates which favored the development of xerophilous shrublands (63\%) and pastures (28\%) (Espinosa et al., 2008). In the low and flat areas, the most abundant shrub species is creosote bush (Larrea tridentata (Moç. \& Seseé ex DC.) Coville) which grows alone or mixed with other drought tolerant species. In addition to the vascular vegetation cover, the area also includes communities of biological soil crusts (BSC). These communities consist of soil particles in association with cyanobacteria, green algae, lichens, fungus, and bryophytes. These biocrusts have physiological qualities such as resistance to desiccation and temporary suspension of breathing, which allow them to develop in environments with scarce water availability (Belnap et al., 2001). 
Several authors have stated that the composition of biological crusts differs depending on whether they are under vascular plants or in open areas (Maestre et al., 2001; Maestre, 2003; Mendoza-Aguilar et al., 2014) and that they might also differ depending on the plant species that they grow under, due to differences in microenvironments. Hence, in this study, the biological crust cover was analyzed in microenvironments under the canopy of the two dominant shrub species (Larrea tridentata (Moç. \& Seseé ex DC.) Coville and Parthenium incanum Kunth) and in open areas. Soil moisture and solar light intensity were recorded for each microenvironment. We hypothesized that i) BSC is positively associated with shrub species, ii) Cover of BSC components is higher in the undershrub microenvironments than in the open area between shrubs, iii) Cover of BSC components differs between the vascular species under which they grow, and iv) solar radiation is more closely related to BSC distribution than soil moisture.

\section{Materials and methods}

\section{Study area}

This research was carried out in an area of xerophilous scrub in the Mexican Plateau floristic Province (Rzedowski, 2006) in the southern region of the Chihuahuan Desert $\left(24^{\circ} 47^{\prime} 11^{\prime \prime} \mathrm{N} ; 100^{\circ} 41^{\prime} 54^{\prime \prime} \mathrm{W}\right)$ in northeastern Mexico at $1900 \mathrm{~m}$ above sea level. The climate of the area is $\mathrm{BS}_{0} \mathrm{k}\left(\mathrm{x}^{\prime}\right)$ : arid, temperate (García, 1981); its mean annual temperature is $15^{\circ} \mathrm{C}$; with an average maximum monthly temperature of $36.6{ }^{\circ} \mathrm{C}$ in April and a minimum of $-4.9{ }^{\circ} \mathrm{C}$ in January (CONABIO, 2016; CNA, 2016). Mean annual rainfall is $429 \mathrm{~mm}$, with a maximum in January (318 mm) (CNA, 2016). Soils are haplic and calcic xerosols with petrocalcic physical phase. These soils support microphyllous desert scrub in the alluvial areas (CONABIO, 2016). This vegetation type, which covers about $49 \%$ of the soil surface, is mainly distributed in flat or very gentle slope areas and it is formed by species that support high concentrations of salts with Larrea tridentata ((Moç. \& Seseé ex DC.) Coville) as the most common species mixed with Fouquieria splendens Engelm, Flourensia cernua DC., Zinnia acerosa DC., Parthenium incanum Kunth, Jatropha dioica Cerv., Koeberlinia spinosa Zucc. and some spiny shrubs (Granados-Sánchez et al., 2011). There is no agriculture in the area, but there is evidence of light cattle and equine grazing.

\section{Methods}

\section{Association analysis}

Plant species abundance and frequency were previously evaluated in the area. We selected the two most abundant species to analyze their association to biological soil crusts. These species were Larrea tridentata (density by $\mathrm{m}^{2}=0.806$; relative frequency $=13.52 \%$ ) and Parthenium incanum (density by $\mathrm{m}^{2}=0.521$; relative frequency $=8.74 \%$ ). Thirty-three interception lines (Canfield, 1941) of $30 \mathrm{~m}$ long were used to record the presence of BSC underneath the two most abundant plant species and in the spaces between them. Lines were established $0.5 \mathrm{~km}$ apart with sampling points every $0.5 \mathrm{~m}$. We analyzed the association between plant species and BSC with a total of 975 points: 537 open area points (105 with BSC; 432 without BSC), 266 under Larrea tridentata (234 with BSC; 32 without BSC), and 172 under Parthenium incanum (161 
with BSC; 11 without BSC). The remaining points fell either on other plant species or on litter.

We tested four microenvironments: i) underneath Larrea tridentata (ULt), ii) underneath Parthenium incanum (UPi), iii) open area (OA) and (iv) underneath vascular plant (Uvp), defined by adding the data of microenvironments i) and ii). Biological soil crusts communities were classified according to the morphology of their components (Eldridge and Rosentreter, 1999) and the following categories were established: lichens, mosses, cyanobacteria, and hepatics, named herein as morphotypes. Endocarpon pusillum (Hedw.) and Collema coccophorum (Tuck.) are the most common species of the lichen morphotype, with frequencies of 70 and $46 \%$ out of the total of lichens. Cyanobacteria morphotype is mainly composed of species of Scytonema and Microcoleus genera. Liverworts are characterized by species of Riccia and Oximitra genera. Mosses were not identified.

\section{Relationships between BSC morphotype cover and plant species at each microenvironment}

Twenty sampling plots $(20 \mathrm{~m} \times 20 \mathrm{~m})$ were randomly selected in the area. At each plot, one individual of Larrea tridentata and one of Parthenium incanum with BSC under them were selected and crusts sampled. Also, biological crusts of corresponding open areas were sampled. Open area sites were sampled at a distance shorter than one meter from the limit of the plant canopy projection to reduce soil variability (Bowker et al., 2006). Six samples were collected from under each plant and six in their corresponding open area; having 20 replicates of each microenvironment with 120 samples each.

Before sampling, the soil surface was sprayed with distilled water to avoid breaking off the crusts, and a sample of the topsoil layer was collected using a Petri dish $(9 \mathrm{~cm}$ in diameter by $1 \mathrm{~cm}$ in depth) taking care that the soil surface remained unaltered. Biological soil crust collected samples were taken to the laboratory to estimate cover by morphotype using a template with 8 radial divisions, stereoscope, microscope, and identification guides (Brodo et al., 2001; Barreno and Pérez-Ortega, 2003; Rosentreter et al., 2007). Percentage cover was visually estimated within each radial division; percentages were then added for each Petri dish and extrapolated to square meter. The soil moisture and solar radiation were recorded at each microenvironment (ULt, UPi and OA). Soil moisture was determined by the gravimetric method and solar radiation was recorded using a luxometer (Extech Instruments, model 401025). Sampling was done from May to December 2014 at different times of the day due to the time required to reach all sampling quadrats; hence, extreme caution was taken to record at virtually the same time all the microenvironments within the same sampling quadrat and data were analyzed as paired $t$ tests (Dytham, 2011).

Chi-square tests $\left(\chi^{2}\right)$ were used to determine association (Dytham, 2011) between BSC and vascular plants. To measure the degree of association, contingency tables $2 \times 2$ were used and the strength of association was determined using Equation 1 (Badii et al., 2008):

$$
V=\left(\frac{a d-b c}{\sqrt{m n r s}}\right)
$$


where $\mathrm{V}=$ Association coefficient; $\mathrm{a}=$ points where both, the plant and the BSC, are present; $\mathrm{b}=$ points where only the BSC is present; $\mathrm{c}=$ points where only the plant is present; $\mathrm{d}=$ points where plants and BSC are absent; $\mathrm{m}=\mathrm{a}+\mathrm{b} ; \mathrm{n}=\mathrm{c}+\mathrm{d} ; \mathrm{r}=\mathrm{a}+\mathrm{c}$ and $\mathrm{s}=\mathrm{b}+\mathrm{d}$.

The data were further analyzed using not only BSC presence-absence data but the percentage cover of each BSC morphotype in each microenvironment. These analyses were carried out for three conditions: i) under Larrea tridentata (ULt), ii) under Parthenium incanum (UPi) and iii) in open areas (OA). The data of the BSC morphotypes cover, solar radiation, and soil moisture were analyzed for normality (Shapiro-Wilk test) and homoscedasticity (Levene test). When data did not meet the former assumptions, a non-parametric analysis was carried out. The comparison of BSC morphotypes cover among the microenvironments was done through the non-parametric Kruskal-Wallis analysis. When significant differences were detected, Mann-Whitney U tests were performed. Solar radiation and soil moisture were analyzed by the Wilcoxon's test as a non-parametric alternative to the Student's t-test for related samples (Dytham, 2011). All statistical analysis was performed using the SPSS $^{\circledR}$ Statistics software version 19.

\section{Results}

Chi-square results showed an association between BSC and microenvironment under vascular plants (Uvp) $\left(\chi^{2}=483.012, \mathrm{df}=2, \mathrm{p}=0.001\right)$; with a positive association intensity of 0.715 . Both plant species showed an association with BSC $\left(\chi^{2}=338.535\right.$, $\left.\mathrm{df}=1, \mathrm{p}=0.001 ; \chi^{2}=313.676, \mathrm{df}=1, \mathrm{p}=0.001\right)$ for Larrea tridentata and Parthenium incanum respectively. Association intensity was positive and similar for both plant species (0.652 for Larrea tridentata and 0.655 Parthenium incanum).

Cover of lichens $\left(\chi^{2}=31.76, \mathrm{df}=2, \mathrm{p}=0.001\right)$ cyanobacteria $\left(\chi^{2}=7.14, \mathrm{df}=2\right.$, $\mathrm{p}=0.028)$ and mosses $\left(\chi^{2}=27.28, \mathrm{df}=2, \mathrm{p}=0.001\right)$ differed among conditions or microenvironments. Liverwort cover was not included in the analysis due to their very low surface cover $(<0.3 \%)$ across samples.

Larrea tridentata microenvironment (ULt) showed a higher cover of lichens and cyanobacteria than Parthenium incanum (UPi) $(\mathrm{p}=0.001 ; 0.031)$ and open areas (OA) $(\mathrm{p}=0.001 ; 0.015)$ microenvironments. The moss morphotype had similar cover in ULt and in UPi and this was higher than in OA $(\mathrm{p}=0.001)$ (Fig. 1).

Water content in the soil was low across sampling dates $(<9.8 \%)$ for all microenvironments and samples. Soil moisture content differed between microenvironments; the highest content was recorded in the ULt microenvironment $(6.36 \%)$. Soil water content for UPi and OA microenvironments were similar $(\mathrm{p}=0.911)($ Table 1).

Solar radiation values ranged from 2,400 to 95,300 lux. The three microenvironments had statistically different solar radiation values (ULt vs. OA $p=0.001$; UPi vs. OA $p=0.001$; ULt vs. UPi $p=0.002$ ). Solar radiation was higher for the OA microenvironment, followed by ULt and then UPi (Table 1).

Cover of mosses was lower in the OA microenvironment which showed the highest solar radiation. Lichens and cyanobacteria cover were not related to solar radiation since their highest cover was in the ULt microenvironment that has an intermediate solar radiation. 


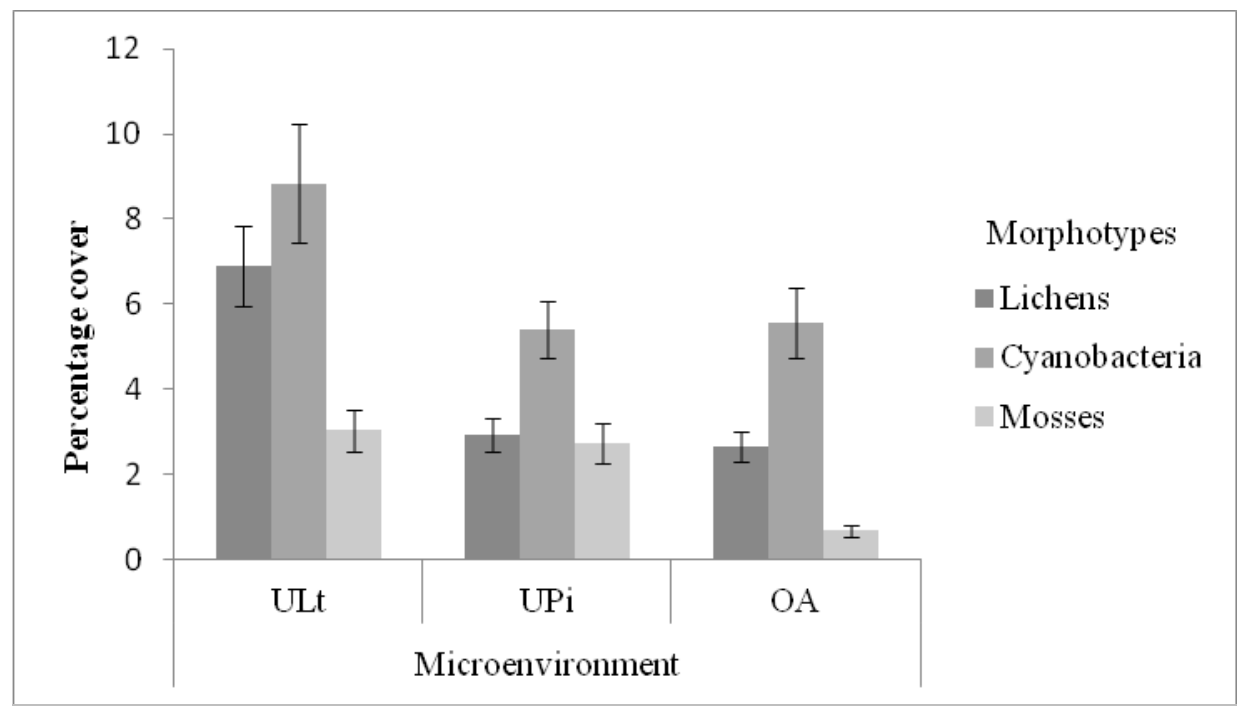

Figure 1. Percentage cover of BSC morphotypes for microenvironment. Error bars are standard errors. $U L t=$ under Larrea tridentata, $U P i=$ under Parthenium incanum, and $O A=$ open areas

Table 1. Solar radiation and soil moisture (mean \pm standard error) for each microenvironment. Different letters in columns are for statistical differences $(p<0.05)$

\begin{tabular}{c|c|c}
\hline Microenvironments & Solar radiation (lux) & Soil moisture (\%) \\
\hline Underneath Parthenium incanum (UPi) & $16253 \pm 24.36 \mathrm{a}$ & $5.49 \pm 0.31 \mathrm{a}$ \\
Underneath Larrea tridentata (ULt) & $29143 \pm 38.61 \mathrm{~b}$ & $6.36 \pm 0.39 \mathrm{~b}$ \\
Open area (OA) & $41018 \pm 40.45 \mathrm{c}$ & $5.48 \pm 0.32 \mathrm{a}$ \\
\hline
\end{tabular}

\section{Discussion}

The results of this study showed an association between BSC and microenvironment under vascular plants (Uvp). These findings are consistent with observations of Maestre and Cortina (2002), who found a positive association between spatial patterns of BSC, composed of cyanobacteria and lichens, and cover patterns of Stipa tenacissima; a dominant plant species in the semi-arid southeast of Spain. Other studies have also shown a facilitative relationship between BSC and plant species, specifically Stipa tenacissim and Cladonia convoluta (Maestre, 2003). Here, both plant species (Larrea tridentata and Parthenium incanum) showed a positive and similar association intensity with BSC.

There seems to be a consensus that vascular plant-biocrust interactions are highly species specific, dependent on the BSC dominating organism's traits and plant characteristics (Rivera-Aguilar et al., 2005; Serpe et al., 2006; Deines et al., 2007). BSC dominated by Diploschistes sp. reduced plant emergence (Escudero et al., 2007; Serpe et al., 2008) maybe due to the sealing of the soil pores by the biocrust which might reduce water availability and thus inhibit germination (Eldridge et al., 2010). St. Clair et al. (1984) found higher germination for three grass species on algal crusts compared with mixed crusts of lichens, mosses and algae. 
Interactions between biocrust and vascular plants could have multiple effects, either facilitative (more soil moisture for the biocrust, more nutrient availability for the vascular plant and biocrust) or inhibitory (less water availability for the vascular plant, lack of sunlight for the photosynthesis of the BSC's photobiont). For instance, biocrust had a negative effect on water availability in an area covered with microbiotic crust in southern China, as rainfall infiltration was about half of that recorded in the area without crust (Uchida et al., 2000). However, in an independent study in the same area, Tateno et al. (2003) found a dependence of Pinus massoniana Lamb. on $\mathrm{N}$ fixed by the microbiotic crust, which improved tree productivity, despite the fact that biocrust decreased the amount of available rainfall.

In contrast, Eldridge et al. (2000) found a significantly higher BSC cover in unvegetated microsites in grazed and ungrazed grasslands in Southeastern Australia than in those with vascular plants. Núñez and Toledo (2013) found that although areas under the shade of vascular plants favor the growth of microorganisms present in the BSC when BSC were analyzed by morphotype, the highest cover of lichens and cyanobacteria was recorded in open areas with higher exposure to solar radiation. Similarly, Mendoza-Aguilar et al. (2014) found a higher cover of cyanobacteria and lichens in the open areas than under plants, which differs to our findings.

We found a higher cover of lichen and cyanobacteria under L. tridentata than in open areas. Even though several authors have found that when the BSC were composed mainly of lichens there is an inversely proportional relationship between them and vascular plants (Belnap et al., 2001; Ochoa-Hueso et al., 2011; Núñez and Toledo, 2013) and that lichens are likely to occupy open areas due to a lower competitive ability with respect to vascular plants in obtaining resources (Löbel et al., 2006), in contrast to our results. Such differences in lichens and cyanobacteria distribution may be due to lower competition for space in our study area, where total cover of lichens, cyanobacteria and mosses under L. tridentata was $18.8 \%$ compared to $54.9 \%$ found by Mendoza-Aguilar et al. (2014) for a semiarid area in Alicante, Spain or 85.34\% in Valle de Quibor, in Venezuela (Núñez and Toledo, 2013). At high densities, competition for space is frequent between components of the BSC (Castillo-Monroy and Maestre, 2011).

Very little has been studied about the effect of competition among the components of BSC. Lichens and bryophytes have chemical compounds that play an important role in nutrient intake (Hauck et al., 2009), so that species with different chemical compounds could benefit greatly if they are associated (Castillo-Monroy and Maestre, 2011), but there can also be competition between them. After studying BSC lichen communities in a gypsum outcrops area in central Spain, Maestre et al. (2008) found that there were fewer species combinations and less co-occurrence of those lichens than expected by chance. These results were in agreement with their hypothesis that BSC lichen communities are mainly structured by competitive interactions.

Competitive interactions between BSC components have been documented, both at the pair and species level, and have concluded that the intensity of competition at the community level increases as aridity increases (Bowker et al., 2010). It is most likely that, in more arid conditions, competition would increase and the lichens that are now distributed under the shrubs, would occupy the open areas. Probably, aridity in regions where lichens are mainly distributed in the inter-shrub spaces is more severe than in our study area. 
Vascular plant canopy tends to favor certain biological soil crust morphotypes over others and may enhance biocrust formation; however, it can also create unfavorable conditions such as depriving crusts of adequate light for photosynthesis or bury the biocrusts with heavy litterfall (Zhang et al., 2016). These, among other factors, may cause vascular species to facilitate or inhibit BSC components.

In this study, we found that cover of lichen and cyanobacteria was higher under $L$. tridentata that under $P$. incanum indicating an association that could be the result of facilitation. This could be due to the higher soil water content recorded for ULt microenvironment and the fact that $P$. incanum has a denser canopy which prevents lichens and cyanobacteria from receiving enough sunlight for photosynthetic processes. $P$. incanum also accumulates more litterfall which may difficult the establishment of lichens and cyanobacteria. A facilitative association was established by Bu et al. (2016) who found that BSC cover exhibited a clear positive correlation with a cover of Artemisia desertorum (Spreng), and a negative correlation with Caragana korshinskii (Kom) and Stipa bungeana (Trin) cover in a temperate, semi-arid Province of Shaanxi in China. Similar results, although studying bryophytes have been reported by Ingerpuu et al. (2005) who found a species-specific facilitative effect between two out of three tested vascular species (a legume: Trifolium pratense L., a grass: Festuca pratensis Huds. and a forb: Prunella vulgaris L.) and two bryophyte species (Brachythecium rutabulum (Hedw.) B.S.G. and Rhytidiadelphus squarrosus (Hedw.) Warnst.). Only the first two vascular plants had a significant effect on bryophytes.

In our study, the moss morphotype had a higher cover in the two microenvironments, with lower solar radiation (ULt and UPi) than in the open inter-shrub spaces (OA). Mosses covered, as an average, four times more surface in the ULt and UPi microenvironments than in the open area. Mosses seem to be related to conditions of lower solar radiation and to tolerate competition from vascular plants better than lichens (Löbel et al., 2006). These results are consistent with those of other authors (Maestre et al., 2001; Ingerpuu et al., 2005; Castillo-Monroy et al., 2010; Mendoza-Aguilar et al., 2014; Haughian and Burton, 2015) who found higher cover of mosses under vascular plants than in open areas.

\section{Conclusions}

The results presented here reveal a positive association between BSC and the plant species Larrea tridentata and Parthenium incanum, compared to open areas; thus confirming our first hypothesis.

The lichen and cyanobacteria morphotypes showed a higher cover under Larrea tridentata (ULt) than under Parthenium incanum (UPi) and in open areas (OA) suggesting a species-specific facilitative association with $L$. tridentata. The moss morphotype had a higher cover in ULt and UPi microenvironments which is perhaps a result of lower solar radiation than in OA.

Distribution of BSC components can be potentially relevant for ecosystem functioning (e.g. hydrophobicity and water re-distribution, $\mathrm{C}$ sequestration and $\mathrm{N}$ fixation). Hence, studies aimed at determining how microclimate could modify BSC distribution would improve our understanding of the functioning of ecosystems. The results reported here make an important contribution to the knowledge of the interactions between vascular plants and biocrust components. 
Acknowledgements. This work was supported by the Universidad Autónoma de Nuevo León (Project PAICYT-UANL; CT277-15).

\section{REFERENCES}

[1] Abed, R. M., Al-Sadi, A. M., Al-Shehi, M., Al-Hinai, S., Robinson, M. D. (2013): Diversity of free-living and lichenized fungal communities in biological soil crusts of the Sultanate of Oman and their role in improving soil properties. - Soil Biology and Biochemistry 57: 695-705.

[2] Badii, M. H., Landeros, J., Cerna, E. (2008): Patrones de asociación de especies y sustentabilidad. - Daena: International Journal of Good Conscience 3(1): 632-660.

[3] Barreno, E., Pérez-Ortega, S. (2003): Biología de los líquenes. - In: Ordenación del Territorio e Infraestructuras del Principado de Asturias y KRK (ed.) Líquenes de la Reserva Integral de Muniellos Asturias Cuadernos de Medio Ambiente Serie Naturaleza 5, Consejería de Medio Ambiente, pp. 65-82. Oviedo, España.

[4] Belnap, J., Kaltenecker, J., Rosentreter, R., Williams, J., Leonard, S., Eldridge, D. (2001): Biological Soil Crusts: Ecology and Management. - U.S. Department of the Interior, Bureau of Land Management, U.S. Geological Survey. Denver, Colorado.

[5] Bowker, M. A., Belnap, J., Davidson, D. W., Phillips, S. L. (2005): Evidence for micronutrient limitation of biological soil crusts: importance to arid-lands restoration. Ecological Applications 15(6): 1941-1951.

[6] Bowker, M., Belnap, J., Davidson, D., Goldstein, H. (2006): Correlates of biological soil crust abundance across a continuum of spatial scales: support for a hierarchical conceptual model. - Journal of Applied Ecology 43(1): 152-163.

[7] Bowker, M. A., Soliveres, S., Maestre, F. T. (2010): Competition increases with abiotic stress and regulates the diversity of biological soil crusts. - Journal of Ecology 98(3): 551-560.

[8] Brodo, I., Duran, S., Sharnoff, S. (2001): Lichens of North America. - Yale University Press, New Haven, Connecticut.

[9] Bu, C. F., Zhang, P., Wang, C., Yang, Y. S., Shao, H. S., Wu, S. F. (2016): Spatial distribution of biological soil crusts on the slope of the Chinese Loess Plateau based on canonical correspondence analysis. - CATENA 137: 373-38.

[10] Canfield, R. H. (1941): Application of the line interception method in sampling range vegetation. - Journal of Forestry 39(4): 388-394.

[11] Castillo-Monroy, A. P., Maestre, F. T. (2011): La costra biológica del suelo: Avances recientes en el conocimiento de su estructura y función ecológica. - Revista Chilena de Historia Natural 84(1): 1-21.

[12] Castillo-Monroy, A., Maestre, F. T., Delgado-Baquerizo, M., Gallardo, A. (2010): Biological soil crusts modulate nitrogen availability in semi-arid ecosystems: insights from a Mediterranean grassland. - Plant and Soil 333(1): 21-34.

[13] CNA, SMN (2016): Comisión Nacional del Agua, Servicio Meteorológico Nacional. http://smn.conagua.gob.mx/tools/RESOURCES/Normales8110/ NORMAL19057.TXT (accessed on 5 March 2016).

[14] CONABIO (2016): Regiones Terrestres Prioritarias de México: Tokio. http://www.conabio.gob.mx/conocimiento/regionalizacion/doctos/rtp_080.pdf (accessed on 27 October 2016).

[15] Concostrina-Zubiri, L., Martínez, I., Rabasa, S. G., Escudero, A. (2014): The influence of environmental factors on biological soil crust: from a community perspective to a species level approach. - Journal of Vegetation Science 25(2): 503-513.

[16] Deines, L., Rosentreter, R., Eldridge, D. J., Serpe, M. D. (2007): Germination and seedling establishment of two annual grasses on lichen-dominated biological soil crusts. Plant and Soil 295(1): 23-35. 
[17] Dytham, C. (2011): Choosing and Using Statistics: A Biologist's Guide. - WileyBlackwell, Oxford.

[18] Eldridge, D. J., Rosentreter, R. (1999): Morphological groups: A framework for monitoring microphytic crusts in arid landscapes. - Journal of Arid Environments 41(1): 11-25.

[19] Eldridge, D. J., Semple, W. S., Koen, T. B. (2000): Dynamics of cryptogamic soil crusts in a derived grassland in south-eastern Australia. - Austral Ecology 25(3): 232-240.

[20] Eldridge, D. J., Bowker, M. A., Maestre, F. T., Alonso, P., Mau, R. L., Papadopolous, J., Escudero, A. (2010): Interactive effects of three ecosystem engineers on infiltration in a semi-arid Mediterranean grassland. - Ecosystems 13(4): 499-510.

[21] Escudero, A., Martínez, I., De la Cruz, A., Otálora, M. A. G., Maestre, F. T. (2007): Soil lichens have species-specific effects on the seedling emergence of three gypsophile plant species. - Journal of Arid Environments 70(1): 18-28.

[22] Espinosa, D. S., Ocegueda, S. et al. (2008): El conocimiento biogeográfico de las especies y su regionalización natural, in Capital natural de México, Conocimiento actual de la biodiversidad, Cap. 1, pp. 33-65. - CONABIO, México.

[23] García, E. (1981): Modificaciones al sistema de clasificación climática de Koeppen. Instituto de Geografía, México, D. F.

[24] Gignac, L. D. (2001): Bryophytes as indicators of climate change. - Bryologist 104(3): 410-420.

[25] Granados-Sánchez, D., Sánchez-González, A., Granados, R. L. V., Borja, A. R. (2011): Ecología de la vegetación del Desierto Chihuahuense. - Revista Chapingo Serie Ciencias Forestales y del Ambiente 17: 111-130.

[26] Gutiérrez, M., Pando-Moreno, M., González, R. H., Mendoza, A. D. (2017): Efecto del micrositio en la composición de costras biológicas del suelo en un área de matorral micrófilo del Desierto Chihuahuense, México. - Interciencia 42(4): 212-217.

[27] Hauck, M., Jürgens, S. R., Willenbruch, K., Huneck, S., Leuschner, C. (2009): Dissociation and metal-binding characteristics of yellow lichen substances suggest a relationship with site preferences of lichens. - Annals of Botany 103(1): 13-22.

[28] Haughian, S. R., Burton, P. J. (2015): Microhabitat associations of lichens, feathermosses, and vascular plants in a caribou winter range, and their implications for understory development. - Botany 93(4): 221-231.

[29] Ingerpuu, N., Liira, J., Pärtel, M. (2005): Vascular plants facilitated bryophytes in a grassland experiment. - Plant Ecology 180(1): 69-75.

[30] Löbel, S., Dengler, J., Hobohm, C. (2006): Species richness of vascular plants, bryophytes and lichens in dry grasslands: the effects of environment, landscape structure and competition. - Folia Geobot 41(4): 377-393.

[31] Maestre, F. (2003): Small-scale spatial patterns of two soil lichens in semi-arid Mediterranean steppe. - Lichenologist 35(1): 71-81.

[32] Maestre, F., Cortina, J. (2002): Spatial patterns of surface soil properties and vegetation in a Mediterranean semi-arid steppe. - Plant and Soil 241(2): 279-291.

[33] Maestre, F., Bautista, S., Cortina, J., Bellot, J. (2001): Potential for using facilitation by grasses to establish shrubs on a semiarid degraded steppe. - Ecological Applications 11(6): 1641-1655.

[34] Maestre, F., Escolar, C., Martínez, I., Escudero, A. (2008): Are soil lichen communities structured by biotic interactions? A null model analysis. - Journal of Vegetation Science 19(2): 261-266.

[35] Mendoza-Aguilar, D., Cortina, J., Pando-Moreno, M. (2014): Biological soil crust influence on germination and rooting of two key species in a Stipa tenacissima steppe. Plant and Soil 375(1): 267-274.

[36] Núñez, R. F., Toledo, B. V. (2013): Variation in composition of the microbiotic crust according to the exposure (sunshine - shaded), in soils of the southern sector of the Barrancos river, Quibor Valley, Lara state. - Revista de Investigación 78(37): 193-212. 
[37] Ochoa-Hueso, R., Hernández, R. R., Pueyo, J. J., Manrique, E. (2011): Spatial distribution and physiology of biological soil crust from semi-arid central Spain are related to soil chemistry and shrub cover. - Soil Biology and Biochemistry 43(9): 18941901.

[38] Puigdefábregas, J., Sánchez, G. (1996): Geomorphological Implications of Vegetation Patchiness on Semiarid Slopes. - In: Anderson, M. G., Brooks, S. M. (eds.) Advances in Hillslope Processes, Volume 2, pp. 1027-1060. John Willey \& Sons, London.

[39] Reynolds, J. F., Virginia, R. A., Kemp, P. R., De Soyza, A. G., Tremmel, D. C. (1999): Impact of drought on desert shrubs: effects of seasonality and degree of resource island development. - Ecological Monograph 69(1): 69-106.

[40] Richer, R., Anchassi, D., El-Assaad, I., El-Matbouly, M., Ali, F., Makki, I., Metcalf, J. S. (2012): Variation in the coverage of biological soil crusts in the State of Qatar. - Journal of Arid Environments 78: 187-190.

[41] Rivera-Aguilar. V., Godínez-Alvarez, H., Manuell-Cacheux, I., Rodríguez-Zaragoza, S. (2005): Physical effects of biological soil crusts on seed germination of two desert plants under laboratory conditions. - Journal of Arid Environments 63(1): 344-352.

[42] Root, H. T., McCune, B. (2012): Regional patterns of biological soil crust lichen species composition related to vegetation, soils, and climate in Oregon, USA. - Journal of Arid Environments 79: 93-100.

[43] Rosentreter, R., Bowker, M., Belnap, J. (2007): A Field Guide to Biological Soil Crusts of Western U.S. Drylands: Common Lichens and Bryophytes. - U.S. Government Printing Office, Denver, Colorado.

[44] Rzedowski, J. (2006): Provincias floristicas de México. - In: Comisión Nacional para el Conocimiento y Uso de la Biodiversidad (ed.) Vegetación de Mexico, México, pp. 104121. http://www.biodiversidad.gob.mx/publicaciones/librosDig/pdf/ VegetacionMx_Cont.pdf (accessed on March 2016).

[45] Serpe, M. D., Orm, J. M., Barkes, T., Rosentreter, R. (2006): Germination and seed water status of four grasses on moss-dominated biological soil crusts from arid lands. - Plant Ecology 185(1): 163-178.

[46] Serpe, M. D., Zimmerman, S. J., Deines, L., Rosentreter, R. (2008): Seed water status and root tip characteristics of two annual grasses on lichen-dominated biological soil crusts. Plant and Soil 303(1-2): 191-205.

[47] St. Clair, L. L., Webb, B. L., Johansen, J. R., Nebeker, G. T. (1984): Cryptogamic soil crusts: enhancement of seedling establishment in disturbed and undisturbed areas. Reclamation and Revegetation Research 3: 129-136.

[48] St. Clair, S. B., St Clair, L. L., Mangelson, N. F., Weber, D. J., Eggett, D. L. (2002): Element accumulation patterns in foliose and fruticose lichens from rock and bark substrates in Arizona. - Bryologist 105(3): 415-421.

[49] Tateno, R., Katagiri, S., Kawaguchi, H., Nagayama, Y., Li, C., Sugimoto, A., Koba, K. (2003): Use of foliar $15 \mathrm{~N}$ and $13 \mathrm{C}$ abundance to evaluate effects of microbiotic crust on nitrogen and water utilization in Pinus massoniana in deteriorated pine stands of south China. - Ecological Research 18(3): 279-286.

[50] Uchida, T., Ohte, N., Kimoto, A., Mizuyama, T., Chnaghua, L. (2000): Sediment yield on a devastated hill in southern China: effects of microbiotic crust on surface erosion process. - Geomorphology 32(1): 129-145.

[51] Zhao, H. L., Guo, Y. R., Zhou, R. L., Drake, M. (2010): Biological soil crust and surface soil properties in different vegetation types of Horqin Sand Land, China. - CATENA 82(2): 70-76.

[52] Zhang, Y., Aradottir, A. L., Serpe, M., Boeken, B. (2016): Interactions of Biological Soil Crusts with Vascular Plants. - In: Weber, B., Büdel, B., Belnap, J. (eds.) Biological Soil Crusts: An Organizing Principle in Dryland. Vol. 226, pp. 385-406. Springer, New York. 